\title{
EXPLORING PATHWAYS TOWARDS AN INTEGRATED DEVELOPMENT ROLE: THE UNIVERSITY OF FORT HARE
}

\section{S. Grobbelaar}

Department of Industrial Engineering Stellenbosch University, South Africa, Centre for Research on Evaluation, Science and Technology (CREST) and DST-NRF Centre of Excellence in Scientometrics and Science, Technology and Innovation Policy (SciSTIP)

Stellenbosch University

Stellenbosch, South Africa

e-mail: ssgrobbelaar@sun.ac.za

\section{G. de Wet}

Dean of Research

Govan Mbeki Research and Development Centre

University of Fort Hare

Alice, South Africa

e-mail: GdeWet@ufh.ac.za

\section{ABSTRACT}

The conditions under which universities are attempting to coherently accomplish their three missions of teaching and learning, research and community engagement have a significant impact on the institutional form, structure and character of universities.

The concept of the developmental state, the role and place for the Higher Education sector in the developmental state and its role in supporting political, social and economic transformation is explored. In this article we attempt to further develop a conceptual framework for the development(al) university considering the context, drivers of focus, and changes in control, governance and university functions to the end of defining a potential development pathway. The research problem addressed in this article is therefore not an attempt to extend the 'research university' or 'entrepreneurial university' concept but to rather discuss the pathways through which a university may strengthen its development role as 'instrument' or 'engine'.

The empirical analysis presented in the article is a case study of an agricultural development project at the University of Fort Hare in South Africa. We analyse the case study against the development pathway framework and explore its utility to facilitate understanding and learning within the University towards reaching development and transformation objectives. We propose that such a framework could support understanding of the impact universities have on the economy and society beyond typical mechanistic measures.

Key words: development university, development pathways, development framework, transformation 


\section{INTRODUCTION - DEVELOPMENTALISM AND THE AFRICAN HIGHER EDUCATION CONTEXT}

\section{A brief history of the developmental state and its relevance in Africa}

Over the past 50 years, internationally and specifically also in the developing world, much discussion has taken place regarding the role of the state in development. During the 1960s to 1970s state-led development was generally encouraged and coincided with independence of many African states where the 'developmentalism’ position was central to development. With many African countries that had a weak private sector the state was forced to take a much bigger role in implementing development policies also with the parallel goal of ruling parties aiming to consolidate power. Many African governments proceeded to facilitate interventionist policies of which many were ineffective as post-colonial states were characterised by weak state capacity, ineffective statist interventions in the national economy, the neglect of fostering a production-oriented private sector; and excessive forms of autocratic and predatory governance (Meyns and Musamba 2010).

This has led to a period when state-led development was criticised during the late 1970s until early 1990s. State-led development was viewed to distort markets, to be inefficient and for a period of time market-oriented reforms and structural adjustment was favoured as part of the Washington consensus. Since the mid-1990s, in view of the success achieved by China and the East Asian Tigers this debate has been revived in South Africa regarding how to achieve a development state which is adapted contextually to the African and South African environment.

\footnotetext{
South Africa has only declared its strategic intent of being a developmental state and it has to work hard to earn that status. It is, therefore, the work of public institutions like higher education institutions that can assist the state to conceptualize and actualize a developmental state suitable to the South African conditions as neither Asian nor Latin American or any other models can be reproduced as they were without factoring the unique historical and contemporary environment of South Africa. (Makhanya 2014).
}

The aim of this article is to further explore this statement and to explore the role of the university to support development and social, economic and political transformation. Here we consider the concept of the development university and its dynamic relationship with policy makers and community in the South African context.

\section{THE ROLE OF THE UNIVERSITY IN DEVELOPMENT - THE CASE OF AFRICA}

The discussion around the development(al) university in Africa is not new and can be traced 
back to a UNESCO conference in 1961 on the Development of Higher Education in Africa, which rang in a development decade entitled 'Year of Africa' (UNESCO 1961). A decade later a UNESCO workshop on the role of universities in Africa produced a statement that all universities must be developmental universities and that government should steer them to play such a role (Cloete, Bailey, Pillay and Bunting 2011).

During this period, the much-lamented 'rate of returns on Higher Education' study by the World Bank found that the returns on Primary Education were higher than Higher Education (HE), and for that reason development efforts were refocused (Heyneman 2003). This contributed to chronic under funding of the Higher Education System (HES) and the delinking of universities from the development discourse and their role in development (Cloete et al. 2011).

In the 1990s and 2000s new evidence pointed to a relationship between investment in HE and economic development, a new call was made to revitalise universities in Africa. A renewed commitment was made in Accra in 2001 when a public mandate was outlined for universities in Africa for serving the intellectual, social and economic needs of the people of the continent (AAU 2004). Soon thereafter, the AAU Declaration on the African University in the Third Millennium (2001) reiterated that universities in Africa should play a role in national development through the global creation, exchange and application of knowledge (AAU 2004).

Casting our view south to South Africa, in which context this article's empirical work is located, a plethora of HE policies have been introduced since the mid-1990s with a core set of transformation demands and messages.

The South African White Paper on Higher Education of 1997 (DoE 1997) acknowledges the central role of the university system in the social cultural and economic development of modern society. In this paper a specific role was defined for the university system for a new social order and a learning society, together with the need to respond to new realities and opportunities in a changing world.

This statement of intent was lately further enhanced by the introduction of the National Development Plan and its strategic expression on the role of universities as drivers of development in the knowledge economy and the output targets associated with the sector's expected performance by 2030 (NPC 2011, 262). These debates, as already indicated, are not new but they are important for the discussion being advanced in this article.

Within this context, it may be argued that the University of Fort Hare is at the centre of the question of how universities in South Africa could or should respond to transformational challenges. In the 1990s during large-scale political change in South Africa, the process was initiated to transform the University from a Bantustan-defined university. A range of core 
functions and processes of transformation, some of them very disruptive, started to permeate the whole system. Large-scale change in management structures and later on the incorporation of the East London Rhodes campus in 2004 provided further impetus to the change.

More recently, following almost twenty years of upheaval, the 2009 to 2016 Strategic Plan was then drawn up in an attempt to focus the university on an underlying developmental role. It was clear that the context and immediate environment should play a significant role in how the university should be positioned.

\section{Problem statement and methods}

Against this background, it is worth considering Wood (cited in Schreuder 2013) who argues that the 'ecology of the university enterprise' refers to the conditions under which universities are attempting to accomplish their role in a 'coherent fashion'. A range of worldwide developments are having an impact on the mechanisms through which universities aim to achieve their three missions of teaching, research and economic and community engagement (Gibb and Hannon 2006).

The pressures of a changing world are compelling universities to adapt and respond to issues such as globalisation, the digital revolution and shifts in public policy. These pressures have a profound impact and are driving a global transformation of the higher education system (Brennan, King and Lebeau 2004; Lucas cited in Schreuder 2013). These global developments are also driving new forms and a new focus of traditional functions in the university where, for instance, funding uncertainty is resulting in new activities and a focus on income generating activities, and knowledge-production processes that have become complex, interdisciplinary, networked and socially shared. The sustainability and impact of knowledge production also require new ways of organising the core functions of HE institutions.

The research problem addressed in this article is the development of an analytical framework for the analysis of the transformation pathway of Development Universities. We critically reflect on the extant literature and continue to deductively develop a pathway framework by exploring a range of forms of the development(al) university. Here we consider key capacity areas, and then apply the resultant analytical framework to a case study of an agricultural project at the University of Fort Hare in South Africa. The aim is to build on the literature by acknowledging the dynamic nature of the transformation process towards a development role in relation to various pressures and barriers resisting change. 


\section{LITERATURE REVIEW: A PATHWAY TOWARDS A DEVELOPMENT ROLE}

\section{The development(al) university}

The role of the university in transformation of the society has been unpacked as to include economic, political, social and the cultural aspects (Brennan et al. 2004). None of these aspects or mutually exclusive and it can be argued that the role in economic development may also have implications on social and cultural issues and vice versa. It is furthermore widely acknowledged that the role of universities has evolved over the past few years with the addition of a third mission of economic and social development emerging to supplement the traditional roles of teaching and research (Gibb and Hannon 2006).

A large body of literature exists on normative studies of universities and there is a growing mass of empirical literature that focuses on the internal changes now taking place in Higher Education in response to its transformational role (Brennan et al. 2004). Various authors have noticed this changing contract between society and universities, the move from 'Mode 1' towards 'Mode 2' of science systems, and the development of models to describe universityindustry interactions, such as the 'Triple helix', the role of universities in innovation systems and the 'entrepreneurial university' (Clark 2004; Etzkowitz 2001; Etzkowitz and Leydesdorff 2000; Gibbons 1999; Jones 2013).

Literature on the exact form and nature of the 'development' or 'developmental' university is not nearly as developed as the literature on the 'research university' or the 'entrepreneurial university'. Although a small number of authors refer to the development university (Brundenius, Lundvall and Sutz 2009; Sehoole and Knight 2013; Cloete et al. 2011).

In the academic literature, the essence of a developmental university can be traced back to Coleman $(1986,477)$ who states '... an institution that in all its aspects is singularly animated and concerned, rhetorically and practically, with the solution of the concrete problems of society'. To illustrate this extent a case study will be addressed in this article. The theoretical conceptualisation of the developmental university in this article should be understood in the context of the presentation of the pathways towards such a state. It serves as an analytical framework.

Against this premise, drawing on Castells and Cardoso's (2005) categorisation of the key functions of universities in developing countries, it is clear that distinguishing between two key focus areas, namely political or socio-economic influence is essential. The focus on political influence is where the university is playing the role of an ideological apparatus for the selection of dominant elites. A third and fourth role relating to economic and social influence are also acknowledged here, namely as the large-scale training of people, capacity building and the 
production of knowledge.

Cloete et al. (2011) provide guidance and a very useful outline for four focus areas for universities from the development(al) university paradigm. As shown in Figure 1, here the classification for universities playing a role in the transformation of society and development is made on two axes, namely (y-axis) acknowledging the university as part of a nation's development strategy, and (x-axis) the role of new knowledge in development. Four broad categorisations can be identified: the ancillary; the self-governing university; the university as an instrument; and the university as an engine of growth. Here, implicitly, the role of government funding has significant implications for the emphasis and focus on teaching, knowledge production and engagement.

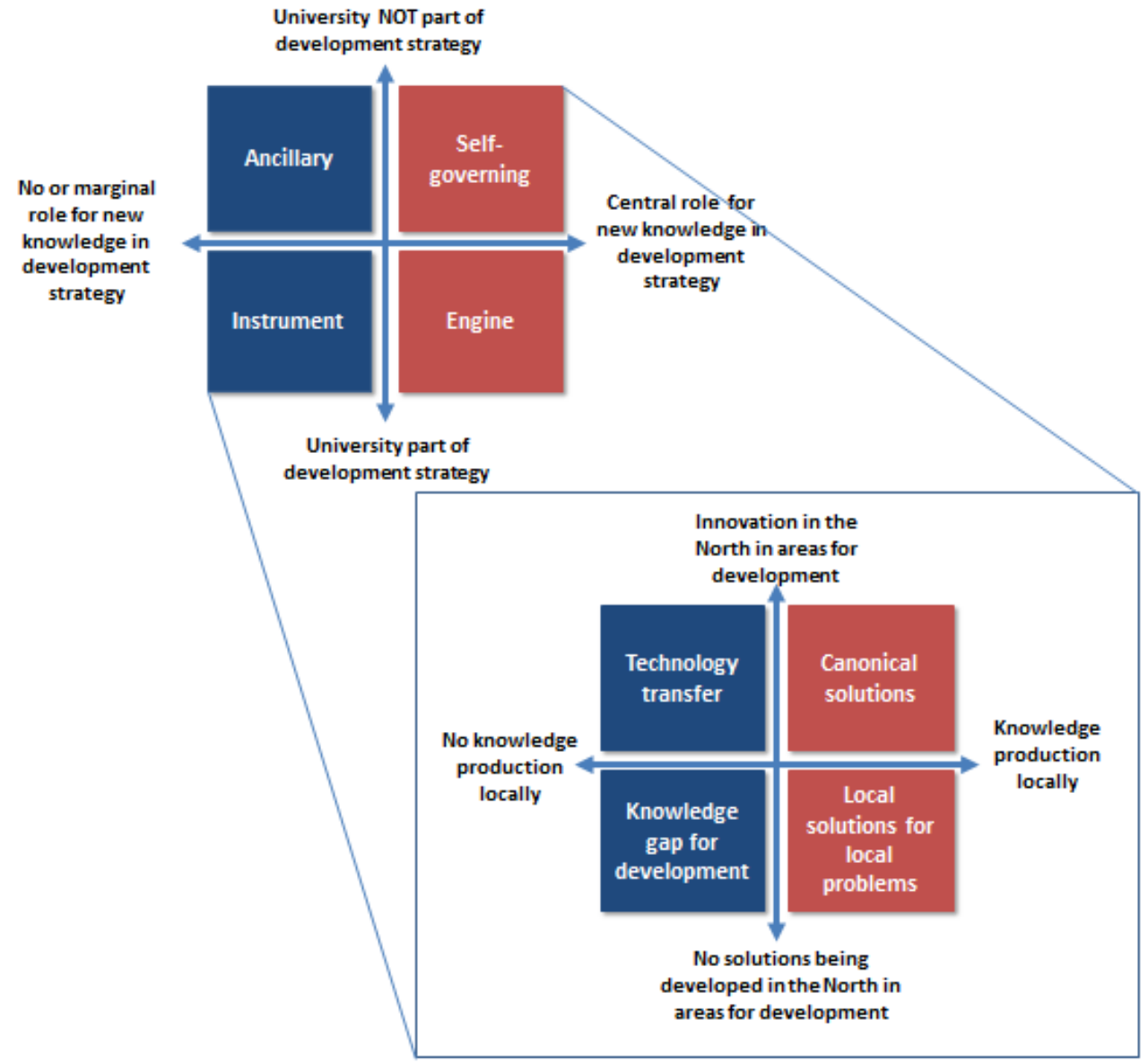

Figure 1: Ideal types for the university and the purpose for knowledge production (Adapted from (Arocena and Sutz 2007; Cloete, Bailey and Pillay 2011).

A second knowledge production paradigm (epistemological) perspective as proposed by Arocena and Sutz (2007) is also integrated into Figure 1, and which emphasises the development nature of the university and the role of knowledge production of such institutions. Here, the focus is on local knowledge production and its relationship with the development of 
knowledge elsewhere. This has implications for how research is organised within the university.

By integrating the insights from Castells (1994) and Coleman (1986), one can more clearly illustrate these four conceptions of the university and consider the range of ideal types of universities.

The ideal form of the ancillary and self-governing university as conceptualised by Cloete et al. (2011) is not recognised by government in their strategy to play a direct role in development. In this instance the university may be seen to be disconnected from the external environment mainly through a lack of demand and recognition of the available resources.

As Cloete et al. (2011) note, the two major roles a university plays as a tool for development is a more direct, service-oriented, 'instrumentalist' role or a role towards an 'engine for development'. As Coleman (1986) rightfully noted, none of the abovementioned forms of the development university is new and examples of these can be traced back to a number of well-known models of universities.

The university as an instrument has an important role to play in national development but not necessarily through the production of knowledge, but rather on its exchange of expertise, and capacity building and political influence. Three instrumental roles can be distinguished from the literature: 1) The 'reconstruction of society', with a prime example being the landgrant universities established in the US in the 1860s (Coleman 1986), 2) The 'man-power development' paradigm with a prime example the Soviet model for the development of manpower through successive five-year plans and the socialisation of manpower in the ideology of the regime referred to by (Coleman 1986; Castells 1994); 3) The 'political socialisation' model playing the role of an ideological apparatus or for the selection of dominant elites (Castells 1994).

The university as an engine refers to an environment where the university is seen as one of the core institutions in the development model. Here the university is seen as a key institution to address complexities in transitioning to a knowledge economy, with a range of functions to develop skills, competencies and to produce applied knowledge. Examples of this are mostly from non-African contexts such as 1) A case of 'industrial development' as illustrated by the Japanese universities that assisted the government in its road to forced modernisation and industrialisation. The role of the university in Japan was seen as assisting the state (not society) in achieving its goal, which was development based on the higher ideals of civilisation and enlightenment (Coleman 1986); 2) The 'entrepreneurial university' framework has been used to describe the role that universities such as Stanford, MIT, Oxford and Cambridge play in supporting economic development in their regions with a key goal of industry formation. Also, particularly in Asia, many case studies have featured universities that are central to the 
development of newly industrialised nations (Gibb and Hannon 2006; Clark 2004; Gibbons 1999).

These high-level conceptions of the development university serve as guiding contours which allow for a broad level distinction of its various forms. It is important to note that these conceptions are based on a range of external factors which include the state's policy of universities in development and also internal factors, such as the forms and foci of its various functions.

Critically reflecting on these categorisations and conceptualisations of development(al) universities brings us to two high-level conceptualisations of universities: The literature has it down as the role or the focus - which is insightful but does not allow us to unpack the process - the pathway through which it may be allowed or prevented from playing a role.

Cloete et al. (2011) highlights the dearth of work and studies that have been completed on the nature and dynamics of the relationship between higher education and development or on the contextual and institutional factors which facilitate or inhibit these relationships. This is especially true for the African context where little has been done to marry national and institutional factors. Cloete et al.'s (2011) study goes to some length to consider the nature of the relationship and cooperation between universities, political authorities and society at large and some consideration is given to the institutional core of the university as well as the evaluative and connected aspects pf the system. A next step to build on this work is taken in this article to consider the dynamic nature and the positive reinforcing loops that exists through which the university can play a development role.

\section{Pathways towards an integrated development role}

Before progressing any further, it is firstly important to acknowledge that universities find themselves in varying contextual conditions that need to be taken into consideration. Universities vary hugely in many ways, for instance in their underlying culture and traditions, the existence or lack of deep and rich scholarship histories, linkages with civil society and industrial enterprises. Also, national and regional characteristics differ, as do their role and

place in government ideologies and histories of commitment to freedom of association (Coleman 1986; Brundenius et al. 2009; Brennan et al. 2004).

In this theory building section, an exploratory attempt is made to take the analysis a step further and to develop a transformation pathway framework. This exercise considers the dynamic nature of a university as it responds and adjusts to a constantly changing environment, while transitioning towards becoming more research intensive institution and playing a wider role in social and economic development. In this section the key aim is to supersede the extant 
literature by acknowledging the process to be dynamic and allows for various levels and focus areas for a university in achieving its three missions. We deductively develop the pathway from the extant literature and aim to allow for the acknowledgement of various levels of capacity and activity and aims to map out a change pathway and also to consider new evaluation concepts to include dynamic behaviour and change.

We develop a largely normative and generic pathway to guide analysis of the transformation of a university into a development role. The intention is that regardless of the key aim and focus of the development university (as instrument or engine), this pathway should provide guidance toward analysing and designing the institutional environment for a development university. For this reason, the focus of political, social economic and cultural influence is not specifically addressed but the process and factors of consideration to align the university to its goals are mapped out.

Brennan et al. (2004) outline distinct periods of transformation starting with a first phase where the focus is on 'removing the old' - mostly about the overthrowing of a regime and the events that led up to that. A second period can be distinguished which is about 'building a new system' in which reconstruction, institution building, new relationships and alliances are developed. The process of transformation may therefore at first be dramatic but become more incremental as the building and development phase continues.

The development of a framework for analysing a transformation pathway of the university environment is useful towards guiding analysis of institutional change to cover a range of areas towards achieving the university's missions, which include the choice of mechanisms and facilitators of change, together with the form and focus of the activities undertaken. Labelling this a framework implies that the flow diagram below (Figure 2) is not a model or theory (which implies the postulation of causal assumptions) but rather a visual aid to help guide the discussion about change in the university. We propose that such a framework may aid in:

- $\quad$ Stimulating debate within the HES around the development role of universities and their place in supporting the achievement of development objectives;

- $\quad$ Sharing learning between teams within universities and beyond on approaches towards the increased societal impact of research;

- Inform the development of a monitoring and evaluation framework for institutional change that goes beyond existing traditional mechanistic approaches.

In order to define a pathway to transformation for a university, it is first necessary to consider the ecology, various barriers and changes in the control and governance of HE, as well as 
changes in the form and focus of teaching and knowledge production, and knowledge dissemination. This section unpacks the various focus areas and suggests an analytical framework for the analysis of such a transformation.

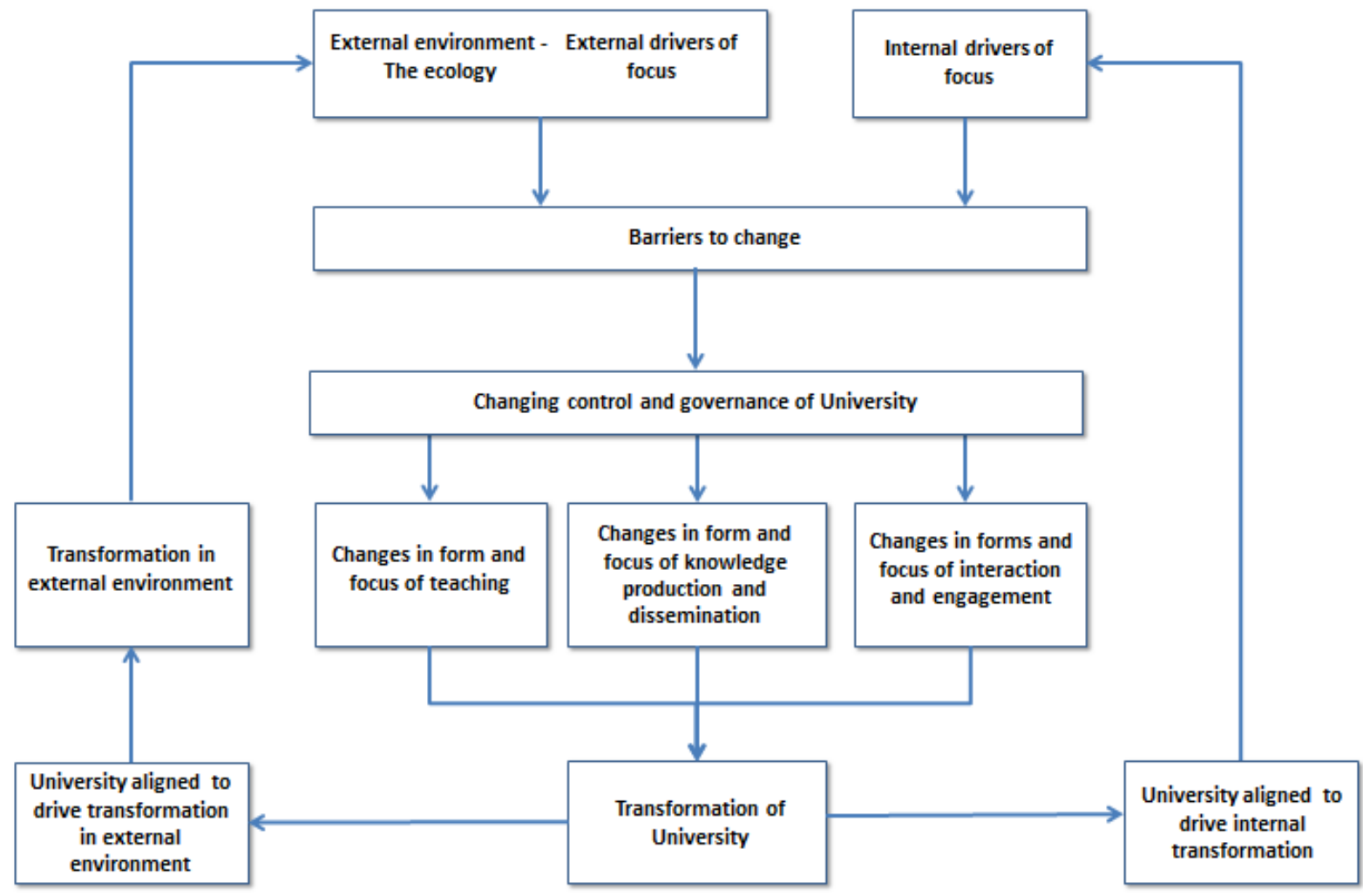

Figure 2: A framework for the analysis of the transformation pathway of the university environment

As far as the ecology of the university enterprise and the external drivers of focus is concerned, developing-country universities face many challenges to establish themselves as researchintensive institutions. Many of these institutions, also in the South African context, find themselves in a rural situation amidst a sea of underdevelopment that is characterised by poverty and desperation. This range of factors that make up the 'ecology of the university enterprise' must therefore be included in the analysis specifically how that relates to relevance and impact. Coleman (1986) suggests these factors to include history and socio-political issues; industrial structure, level of development and productivity; participation of the populace in HE and the enrolment gap; the profile of the disease burden; quality and accessibility of services; poverty and income levels and the effects of globalisation and internationalisation (Brundenius 2009).

As far as external issues that drive interaction are concerned, recalling Cloete's (2011) framework, the inclusion of the university in development planning by government was one of the key determinants for the character and role of the university in development. This may include the extent to which Higher Education is linked to regional development or the level and 
drivers of responsiveness to labour market demand (Cloete et al. 2011; Pillay 2011). There are therefore many trade-offs in balancing the corporatization of university functions with a view to create financial sustainability, sometimes at the expense of a scholarship-driven vision (Brennan et al. 2004).

The alignment of the university with the needs of the external environment may also be affected by its sources of funding and the power relations, the forces of globalisation and internationalisation and expectations of government. The literature cautions that Government sometimes expects too much of universities and their impact on transformation objectives (Coleman 1986). It is therefore a balancing act to ensure appropriate government support and leveraging political will to implement and use research outcomes, and on the other hand to ensure continued autonomy of the Higher Education System (HES) (Cloete et al. 2011; Pillay 2011).

Secondly, there are typically a host of external and internal barriers to play a developmental role that can be identified for universities in these contexts. With many of the factors mentioned in the earlier paragraph that can also be argued to be external barriers, internal issues may include a lack of funding, time pressures on staff and uncertainty about funding sources, coupled with difficulties in attracting the best faculty and students (Grobbelaar and Kirkland 2013). Furthermore, cultural issues, such as a lack of scholarly focus and leadership, could result in research and teaching not addressing issues relevant to the local environment, or a poor fit between the available academic capabilities and development needs. As far as driving transformation towards a development role, the inherent conservatism that characterises the HES may result in a very slow rate of change in institutions and act as a significant barrier to playing a development role (Coleman 1986).

In the third instance, through the transformation of the university enterprise, change may be driven through changes in the control and governance of the university. This may include changes in policies, structures, infrastructure and engagement mechanisms (Grobbelaar and Kirkland 2013). Here, as far as resourcing and planning is concerned a development university needs to ensure that development outcomes should be considered when choosing and allocating funding to projects and project planning. Furthermore, as far as structure and support mechanisms are concerned, the university should develop mechanisms for and support staff in developing networks and partnerships (through inter alia innovation platforms). The university should also recognise staff engagement activities by means of internal rewards and incentive systems, and consider the inclusion of support for Monitoring and Evaluation (M \& E) on projects and systems in the university to track engagement, and share learning and success stories. 
Fourthly, governance mechanisms are needed to ensure there is a synergy between teaching, research and engagement, and to create a learning environment that supports such synergies. This raises the important issue of multi- and trans-disciplinary project initiation platforms or innovation platforms in order to ensure there is a rich and comprehensive approach and common learning between disciplines. Furthermore, the university must have a clear code of ethics through which development activities and relationships take place (Grobbelaar and Kirkland 2013).

As a fifth focus area, and as far as the first mission of teaching is concerned, the focus and form of teaching needs to be aligned with development objectives specifically in terms of addressing the enrolment gap and widening participation, cooperation with local enterprises and communities for relevant skills development and continuous education and multi- and trans-disciplinary training (Arocena and Sutz 2007; Brundenius et al. 2009).

As a sixth focus area, the form and focus of the research mission and agenda of the university may be a good reflection of its actual role in development, as the focus of the research conducted will reveal the intricate web of interest, power and voices within and outside the university. The nature and level of knowledge production and attempts to strengthen such activities may be an important part of a transformation drive in the university (Arocena and Sutz 2007). Components affecting the epistemology of the development university - the process of knowledge production and the use of knowledge through multi- and trans-disciplinarily research approaches - have implications for the setup of the university and dictate its structures, systems, groups, channels of knowledge dissemination, and the development of research questions. Here, for instance, a university may consider orienting the research agenda to focus on social-inclusion concerns, and this may, in turn, require particular research methodologies, such as participatory or action research methodologies (Arocena and Sutz 2007). Consideration should also be given to focus research activities on developing an evidence-base for policy, advocacy and management (Wilson and Cornell 2012).

The changes in form and focus of the university as far as engagement is concerned, have implications for the way in which the university engages with the external environment and the accessibility of knowledge resources in the university to outside players. Having a wide view of extension, leveraging not only staff but also students and community members is a core prerequisite to ensure having a scholarship-enhancement base which draws on knowledge developed through engagement and infuse it into core curricula and research agendas (Arocena and Sutz 2007). Also, a development university needs to ensure the development of sustainable networks and relationships (rather than short-term 'random' interactions) with key development agencies and users (Grobbelaar and Kirkland 2013). This needs to drive a dynamic not only to 
improve relationships with the external environment, but also to improve accessibility to university resources (Wilson and Cornell 2012) (Brundenius et al. 2009).

The literature also refers to the development of infrastructure (e.g. intermediary systems and structures and extension functions) to support outreach and development support. This may include establishing structures such as institutes, centres and units to conduct research and to ensure that societal impacts are facilitated. Such intermediary structures could also include multi-stakeholder initiatives for collaborating with state departments, the private sector or the NGO / CBO sector and playing the role of ‘change agents’ (Wilson and Cornell 2012).

In conclusion, Table 1 summarise the key attributes and the author's conceptualisation of a developmental university.

Table 1: Key characteristics of the development(al) university

\begin{tabular}{|c|c|}
\hline $\begin{array}{l}\text { Key goals and } \\
\text { nature of the } \\
\text { university }\end{array}$ & $\begin{array}{l}\text { - Depending on the type of development university: social and political objectives integrated in } \\
\text { core missions of the university enterprise } \\
\text { - University is open and interacts with different groups in society specifically integrated in } \\
\text { development planning by government } \\
\text { - Role for university in capacity development and transformation and redress e.g. enrolment gap } \\
\text { - Orient teaching and research towards social inclusion and concern } \\
\text { - Student and staff involvement in development activities and engagement }\end{array}$ \\
\hline $\begin{array}{l}\text { Functions of } \\
\text { the } \\
\text { developmental } \\
\text { university }\end{array}$ & $\begin{array}{l}\text { - Transformation focus social, political economically and cultural resulting in changes in } \\
\text { universities in terms of curriculum, quality and standards; diversification; access policies, } \\
\text { student profiles and experiences; and academic responses to change. } \\
\text { - Teaching focused on local relevance, lifelong learning, adult education and entrepreneurial } \\
\text { training } \\
\text { - Research: Applied research to assist development and to provide evidence based for policy } \\
\text { and practice } \\
\text { Economic and social development: agricultural extension, health outreach, adult education, } \\
\text { extension classes and the diffusion of knowledge and innovations through the mass media }\end{array}$ \\
\hline $\begin{array}{l}\text { Policies of the } \\
\text { developmental } \\
\text { university }\end{array}$ & $\begin{array}{l}\text { - University plans aligned with national development plans } \\
\text { - } \text { Coordinate activities strong linkages with helices } \\
\text { - Incentive system to reward staff and students that contribute to development and innovation } \\
\text { - Infrastructure to support innovation, outreach and development support (e.g. intermediary } \\
\text { platforms and training) }\end{array}$ \\
\hline $\begin{array}{l}\text { Obstacles and } \\
\text { barriers }\end{array}$ & $\begin{array}{l}\text { - Government and political will } \\
\text { - University autonomy and the critical function } \\
\text { - } \text { Competence of staff to support development } \\
\text { - The fate of traditional university functions } \\
\text { - Expecting too much of universities }\end{array}$ \\
\hline
\end{tabular}

In applying the analytical framework as discussed above, the transformation pathway of the University of Fort Hare towards a development university will now be considered. The aim as outlined earlier, is to acknowledge the dynamic nature of the transformation process.

\section{CASE STUDY: FORT HARE UNIVERSITY}

\section{A brief history}

The establishment of the University of Fort Hare in 1916 was inextricably linked to the activities of the British missionaries in the area at the time with their focus on the education of 
African people. The historical and political context of Fort Hare never allowed the institution to develop a research-intensive mission for itself prior to the advent of democracy. Although institutionally research was coordinated by a Senate Research Committee that can be traced back to the 1980s, the post-1994 period compelled the university to redefine itself as a HE institution, but it was not until 2004 that its research and developmental mission started to receive intensified attention (Govan Mbeki Research and Development Centre 2009; De Wet 2013).

The dramatic change in research output since 2007 / 2008 demonstrates clearly that a very different 'culture of research' has started to emerge at the University. For example, the doctoral output has grown from only ten in 2007 to 47 in 2012, a growth of more than 700 per cent in six years, and the accredited-paper output over the same period grew from 64 units to 208.57 units. (The Faculty of Science and Agriculture produced almost $80 \%$ of all the accredited research output (De Wet 2013)).

\section{THE UNIVERSITY'S STRATEGIC RESEARCH VISION AND ITS STRATEGIC PLAN FOR RESEARCH}

In 2008 the University embarked on the strategic repositioning of its core business. This resulted in the development of the Strategic Plan 2009-2016 (Fort Hare 2009) which incorporated some aspects of the 2000 and 2004 Strategic Plans.

The University’s 2009-2016 Vision states that it aspires to become a vibrant, equitable and sustainable African University committed to teaching and research excellence. This Vision is underpinned by a mission statement that promotes the core developmental challenges, for example the meaningful and critical participation in the social, economic and political development of society, as well as applying knowledge that contributes to the scientific technological and socio-economic development of the nation and the wider world. Thus, emphasis was clearly placed on the envisaged developmental role of the University.

\section{Pathways to a development role}

\section{Background and orientation}

Two important development drivers must be looked at. Firstly, the need and almost embarrassing realisation that Fort Hare's presence of almost a hundred years has forced its communities in rural Alice and further afield to raise the question: 'How have you contributed to the improvement of the quality of our lives because we experience very little evidence of the sustained impact of your presence in this area?'. 
Secondly, the renewed emphasis on community engagement, the societal impact of research and the continuous recognition through policy initiatives by funders and policy drivers has prompted the University to refocus its philosophy and understanding of what community engagement should be. With strong inputs from the community, the scope and focus were shifting towards a strong participatory and sustainable approach, which will be looked at in the case study.

\section{THE FACULTY OF SCIENCE AND AGRICULTURE: A CASE STUDY}

By about 2004, after the very difficult times in the 1990s of getting the University back on firm footing, a strong realisation was developing that the newly merged Faculty of Science and Agriculture had to reposition itself in relation to its impact on the rural farming communities. Fort Hare is well known for its Agriculture Faculty and the work that has been done towards rural development. But there was a realisation under the then leadership of Prof Jan Raats that a much more sustainable and structural approach to rural agriculture had to be developed, one with direct societal impact. The development of the AgriPark model started to emerge with substantial support from all stakeholders, both internal and external. A very intense period of participatory planning and decision-making followed, which resulted in major funding from Government and other core stakeholders. Lategan and Raats (2008, 14-19) succinctly state that: '... the basic objectives of food and agricultural research, community partnering, and teaching and research programs are to make the maximum contribution to the health and welfare of people and the economy of the country through the advancement of rural enterprises, to improve community services and institutions, to increase the quality of life in rural areas, ...'.

Against this background, one case study, namely the Nguni Project, is presented. The central objective of this project, which commenced in 2004 and which was incorporated into the AgriPark model, was to re-introduce indigenous livestock to traditional cattle farmers and to develop an international niche market for organic, healthy Nguni beef through the large-scale implementation of the 'Fort Hare model'. The aim was to upgrade about 75000 of the communally-owned, non-descript cattle in the province to Nguni status. This was made possible through the introduction of quality Nguni bulls.

The project is supported by the Industrial Development Corporation (IDC) as well as by the Eastern Cape Department of Rural Development and Agrarian Reform (Fort Hare 2014, 34). Currently almost 90 communities in the Eastern Cape are members of the project. A central herd or pool of 700 animals was established as a breeding herd that supplies animals to the community farmers.

By 2012 the project had grown to 2,300 animals (Fort Hare 2014, 34). Local farmers are 
supported by commercial farmers and other farming practices provided by the Nguni Commercial Farmers Association. A total of 46 commercial farmers are involved. The development of the Nguni herd in communities is based on the 'passing of the gift model'. This means that each participating farmer, for instance, receives a few animals to breed with from the central Nguni pool of animals cared for by the University in association with the commercial farmers, and after a year or two the heifers are then passed back to the central Nguni herd, and these animals are then passed on to other communities to benefit from. Repeating the 'passing of the gift' ensures the project's sustainability.

Current activities involve:

- $\quad$ Organising local Nguni auctions for selling and buying breeding stock;

- $\quad$ Creating a support system for farmers (i.e. training Extension Officers and secondments to villages);

- $\quad$ Creating niche markets for quality Nguni meat;

- $\quad$ Creating genetic-improvement programmes to improve the genetic quality of rural stock and thereby improve the production potential of the cattle herd;

- Ensuring that veterinarian services are available, in co-operation with the Eastern Cape Agriculture Department.

\section{CRITIQUING OF CASE STUDY}

The transformation pathway framework proposed in this article provides an opportunity to critique the study, with the view to using it to understand the complexities of transformation and the attempts being made to reposition the core foci of the University. It is important to note that no attempt is made to appraise the university as a system in this analysis, although some system-level mechanisms for implementing change deemed relevant to the case study are outlined. It is, however, posed that critical lessons can be learnt that will take the developmental model to new levels of inclusion and complexity.

\section{The ecology, external and internal drivers of focus}

The role of the socio-political context of the University is discussed in terms of systemic issues and then internal drivers of focus more directly related to the case study.

The University faces a HE landscape that is in transition with huge demands from government, the corporate world and civil society. These demands include things such as aligning to government policy frameworks, the demands for skills development to address 
unemployment, poverty and other social ills, and the demand to be relevant as a knowledgeproduction institution in its immediate context.

The need to provide support programmes with low budgets, the challenge of recruiting young black professionals who are willing to work for low remuneration and in the relative isolation of a rural campus such as the Alice campus, are some of the systemic barriers that need continuous attention. This puts a huge amount of stress on the sustainability of the system.

Internally, the University is still struggling to deal with the institutional backlogs that have not been addressed since the dawn of democracy, such as huge infrastructure shortages, poor teaching- and learning facilities, lack of resources to support research and the challenging demands of being based in a rural and poverty stricken environment. The University faces resource capacity challenges, including caring for a large group of poverty-stricken and, in many cases, underprepared students.

These challenges are also tied to the historical and socio-economic realities of the Eastern Cape and the country as a whole. The role of universities as development and knowledge production agencies is a central question in this respect. The need for sustainability linked to impact and quality-of-life issues is a major concern. On the one hand the University has a reputation as an academic institution to uphold but on the other it also has a responsibility to make a lasting impact on the quality of life of the surrounding poverty-stricken community. From this standpoint, the Faculty of Science and Agriculture realised that a sustainable strategy had to be developed to make a success of these initiatives. An intermediary platform, built on the values and practices of participatory development, was needed to strengthen capacity, improve quality and ensure sustainability. However, this never materialised due to lack of funding and internal rivalry between the key role players, and the University had to develop new mechanisms for dealing with such challenges.

Two very significant strategic interventions on the organisational level were the development of the 2009 to 2016 Strategic Plan and the establishing of the Community Engagement Directorate.

\section{Barriers to performing a developmental role}

Kruss and Gastrow $(2013,26)$ in their research on the interaction between towers of learning and poor communities say that academics should not be expected to play the role of development agencies. The university's distinctive role lies in extending its scholarship to the benefit of marginalised communities. A pressing is question how to achieve this. The University had to face that it could no longer carry on with its core business and continue to pretend that 
it had an impact on the quality of life of its immediate communities. Driven by this acknowledgement, the question was how the institution could become an agent of development.

The need for good, sustainable relationships and projects that have an impact on society are defining aspects that are embedded in the relationship between the University and its surrounding communities. The development of an intermediary facilitating platform to enhance sustainability and quality based on the quadruple helix model (university, community, government and non-governmental sector) seems to be a way around the dilemma expressed by Kruss and Gastrow (2013). The need for good information and educational material must be informed by continuous research done on such projects. The transdisciplinary nature of these projects provides endless opportunities for researchers to contribute to societal change.

Firstly, establishing and managing such an intermediate facilitatory mechanism posed major barriers. In particular, it was difficult identifying and gathering role-players who had the legitimacy, interest and knowledge to enhance quality of life in a sustainable way, and secondly, to develop the necessary skills to manage the expectations of the beneficiaries carefully through troubled periods.

In 2008 a proposal was accepted to establish an intermediary development platform involving all the key role-players thus creating an environment highly conducive for improved training, research and partnering activities and setting the scene for local and international collaboration (Lategan and Raats 2008). This platform intended to achieve the following:

- Improve the efficiency of general agricultural production through continuous training and research;

- $\quad$ Create marketing opportunities for excess production;

- $\quad$ Add value to agricultural produce in order to increase profit margins.

The intended platform was to continuously strive to ensure that quality and sustainability would be promoted through direct community inputs in terms of expertise, needs and challenges, as well as through ongoing research to enrich the developmental processes and practices. This would be done by guiding the research of postgraduate students with the view to influencing developmental practices in a direct way. Societal impact would then be facilitated through the ongoing REAP (Rural Education Access Programme) training and capacity-development programmes and projects. However, REAP, in spite of receiving institutional support, never got off the ground.

The dynamics of working with multiple stakeholders in an environment fraught with expectations pose serious challenges to the ultimate success of such projects. The time and 
commitment required to make a success of a community development project far exceeds the time and energy that a researcher would be able invest on his or her own, in addition to all the other demands placed on the academics.

Another critical barrier is the harvesting of research findings and the implementation of such findings. As most researchers do not have the means and capacity to implement findings without additional support, the hope that other researchers pick up on the findings is all that remains.

Under these circumstances a key learning from this case study was that the best universities can do is to provide the space and supporting means to establish such an intermediary platform and for researchers to continuously feed research results back into the system for sustainable renewal and growth. The incubator function is crucial.

\section{Changes in the control and governance of the university}

The period after 2004 can be regarded as the beginning of the University's settling down after a decade and a half of uncertainty and sustainability challenges. This is evident in terms of the restructuring of the faculty system, the investments in research administration and capacity development, better financial control and the appointment of, for example, a Dean of Research and a Deputy-Vice Chancellor of Academic Affairs. The years since 2007 have seen a dramatic increase in all forms of accredited research output, as stated earlier on.

This period also bears testimony to the University's attempts to manage sustainable networks and relationships with local and international communities. The establishment of the International Relations Office was one such positive development. This office facilitates mobility and exchange programmes, and assists with the development of the scholarship programme, from which a large number of postdoctoral and visiting fellows benefit.

Development activities with a research focus are recognised through the allocation of resources. An annual research budget makes provision for funded research activities and provides seed funding for the purchasing of research and laboratory equipment. The University has nineteen associated entities such as Institutes, Centres and Units all of which also receive some support. These entities operate with strong development agendas.

The University also provides support to staff for engagement with industry and the research community through the Tech-Transfer and Intellectual Property function. This has been a very positive development with a regional Tech-Transfer Office assisting with the protection of intellectual property (IP) and the sourcing of seed funding towards the registration of patents. The Technology Innovation Agency (TIA) has also provided seed funding to a number of patents, which are being considered for potential commercialisation. The Senate 
Tech Transfer and Innovation Committee, established in 2013, monitor the development activities, and relationships are governed by a clear code of ethics which falls into the domain of the University Research Ethics Committee. Progress on development is actively monitored by these structures, which also bring together the staff who work on developmental issues, although this is still at an early stage. Unfortunately, the system is still fragmented, and there is a lack of facilitation and governance. Clearly, changing the existing culture is taking time.

\section{Changes in form and focus of teaching}

The University realises the importance of knowledge in action in its core business of teaching and learning, research and community engagement. The Strategic Plan refers to the integration of these core elements which should be embedded in the development of curricula and in the humanizing pedagogy of care. Special efforts are made to run workshops on these aspects, tapping into the lessons learnt through community-based development and research projects.

Case studies provide excellent opportunities for academics to enrich their teaching and curricula through practical applications. In addition, their research and knowledge production are richly informed by case studies, again through their practical and contextual applications. Several postgraduate and postdoctoral fellows have been linked to these projects over the years with very rewarding results. The research methodology based in participatory frameworks enriches the depth and quality of research projects. This leads to new insights into the complexities of the environment and the challenges that accompany knowledge production and the dissemination of results. The University encourages academics to disseminate their research results freely through its academic writing and conference-attendance policy.

The forms of engagement with academics and stakeholders require special attention. The power relations between communities, academics and other partners pose a serious challenge. One of the most serious matters to navigate is the unrealistic hopes and expectations that many communities have about the impact and change the University can make to their immediate material condition. Sensitivity is required in understanding and managing cultural customs and to treat people humanely. The University's policy on community engagement is highly sensitive to this matter, realising that communities are caught up in poverty and desperation. This also means that they can make sensible contributions about their own situation. This is a key factor and one that influences the forms and focus of interaction and engagement. Not only is this a deciding factor in the research development context but it is also evident in the stance the institution takes on a humanizing pedagogy that underpins their teaching and learning, as well as their community engagement initiatives. 


\section{Changes in form and focus of knowledge production and dissemination}

A huge increase in research output has been recorded over the past seven years that is attributable to the leadership contributions of the Faculty of Science and Agriculture. Their link with community-based projects has been a defining factor in this regard. Many researchers were forced to identify and obtain grants from externally based funders. However, not only were they highly successful in tapping into funding from the South African Science system, but many of them were also highly successful in obtaining funding from other national and international funders. These monies are mostly for funding community-based research projects. In addition to this, the University has set minimum output targets for senior researchers. The prioritising of Science and Agriculture and Education as vital, scarce-skills disciplines were another major strategic decision. This, however, does not mean that other faculties are viewed as less important. This process of prioritising and focusing knowledge production more intensively received further impetus from the restructuring of nine Research Niche Areas, four of which were established in the Faculty of Science and Agriculture. A significant aspect of these Niche Areas is the requirement of trans-disciplinary teams of researchers. Trans-disciplinarity invariably leads to a strong anchoring in community-based involvement. It was a strategic decision to take these initiatives towards becoming a much stronger knowledge-focused institution. However, knowledge in action remains a major challenge for the institution in the context of a developmental paradigm.

\section{Changes in form and focus of engagement}

The decision by the University to establish a Directorate of Community Engagement in 2009/10 was influenced by the strong realisation of the contextual and immediate need to engage with key stakeholders in a developmental way. The Faculty of Science and Agriculture at the time had a very rich history of community engagement through project research and related initiatives. Community Engagement was not in the first instance about 'doing good'. The relationship between the Directorate and researchers is a positive one that is increasing in value and quality. A series of capacity-development workshops is being conducted and includes teaching on how to enter community spaces. Every faculty has now a deputy dean tasked with a community-engagement portfolio, and quarterly reports need to be submitted to the Senate Committee on Community Engagement. Steering and supporting faculties to fulfil their community-engagement mission have been firmly established. In spite of all these measures, the accusation that researchers come into communities, get data, establish findings, get their qualifications, read papers all over the world and never to care enough to plough these findings back into communities, remains a serious matter. 


\section{CONCLUSION}

The article started out by emphasising that the conditions under which universities attempt to accomplish their three missions of teaching and learning, research and community engagement in a coherent manner, have a significant impact on the institutional form, structure and character of universities.

This was addressed firstly by a literature study that pointed out the complexity of the environment in which universities operate as agents of development. An analytical framework that illustrates the concept of a developmental university was used to analyse an agricultural case study, which revealed the complexities that confront researchers at the University of Fort Hare.

In this article we explored the utility of the framework for sharing lessons learnt from a development initiative at the project level. This highlighted the need to establish and develop an intermediary platform that would facilitate the sustainability of these projects and the implementation of research findings back into the target communities. Transformation in this regard relates in the first instance to the scholarly value of these projects and secondly the sustainable impact on the quality of life of the communities involved. Transformation also has systemic and structural components related to the development and implementation of policies and the governance of such systems and structures, which the case study illustrated.

The following framework provides an overview of the interrelated complexities that are deemed to be core actions, processes and functions which drive the University of Fort Hare towards a greater sense of connectivity and developmental engagement. A number of lessons can be extracted from the critique.

Table 2: Summary transformation pathway for University of Fort Hare

\begin{tabular}{|c|c|c|c|c|}
\hline & $\begin{array}{l}\text { What was our } \\
\text { problem? }\end{array}$ & Dynamic sought? & $\begin{array}{l}\text { Systems level } \\
\text { implementation }\end{array}$ & $\begin{array}{l}\text { Project-level } \\
\text { implementation }\end{array}$ \\
\hline $\begin{array}{l}\text { Changes in form and } \\
\text { focus of control and } \\
\text { governance of the } \\
\text { university }\end{array}$ & $\begin{array}{l}\text { Ecology and external } \\
\text { drivers of focus which to } \\
\text { redefine and focus the } \\
\text { core mission and an } \\
\text { alignment with } \\
\text { government frameworks. } \\
\text { Demands for skills } \\
\text { development to address } \\
\text { unemployment and } \\
\text { relevance as a } \\
\text { knowledge-producer and } \\
\text { to identify and deal with } \\
\text { barriers to performing a } \\
\text { development role. } \\
\text { Poverty-stricken rural } \\
\text { area contributes to a low } \\
\text { enrolment gap and }\end{array}$ & $\begin{array}{l}\text { Becoming a vibrant } \\
\text { equitable and } \\
\text { sustainable African } \\
\text { University, } \\
\text { embedded in local } \\
\text { context without } \\
\text { losing universal } \\
\text { connectivity with } \\
\text { mechanisms to } \\
\text { feed research back } \\
\text { into community for } \\
\text { systems' renewal, } \\
\text { growth and } \\
\text { relevance. }\end{array}$ & $\begin{array}{l}\text { Establish a central } \\
\text { research office and } \\
\text { restructured the } \\
\text { faculty system } \\
\text { supported by an } \\
\text { international } \\
\text { Relations Office } \\
\text { established to } \\
\text { maintain links with } \\
\text { local and } \\
\text { international } \\
\text { stakeholders. } \\
\text { Establish an IP } \\
\text { Office and Tech } \\
\text { Transfer with seed } \\
\text { funding form TIA. } \\
\text { All supported by an }\end{array}$ & $\begin{array}{l}\text { Case studies - } \\
\text { action plans to } \\
\text { impact on quality } \\
\text { of life and also } \\
\text { societal impact. }\end{array}$ \\
\hline
\end{tabular}




\begin{tabular}{|c|c|c|c|c|}
\hline & $\begin{array}{l}\text { What was our } \\
\text { problem? }\end{array}$ & Dynamic sought? & $\begin{array}{l}\text { Systems level } \\
\text { implementation }\end{array}$ & $\begin{array}{l}\text { Project-level } \\
\text { implementation }\end{array}$ \\
\hline & $\begin{array}{l}\text { poverty as well as to } \\
\text { attracting talented people } \\
\text { and black professionals } \\
\text { to work in rural Alice. } \\
\text { Internal barriers such as } \\
\text { infrastructure shortages, } \\
\text { poor teaching and } \\
\text { learning and research } \\
\text { facilities. }\end{array}$ & & $\begin{array}{l}\text { annual budget and } \\
\text { seed fund for } \\
\text { sustainability and } \\
\text { growth. }\end{array}$ & \\
\hline $\begin{array}{l}\text { Changes in form and } \\
\text { focus of teaching }\end{array}$ & $\begin{array}{l}\text { Key questions remain: } \\
\text { What role would } \\
\text { researchers play in } \\
\text { development and are } \\
\text { researchers developers } \\
\text { and what is expected } \\
\text { from them? }\end{array}$ & $\begin{array}{l}\text { Change in focus of } \\
\text { core functions } \\
\text { through curricula } \\
\text { development and } \\
\text { pedagogy of care } \\
\text { with a university } \\
\text { strategic plan that } \\
\text { prioritises the } \\
\text { integration of core } \\
\text { elements and that } \\
\text { promotes between } \\
\text { functions to } \\
\text { promote trans- } \\
\text { disciplinarily. } \\
\text { An as a key } \\
\text { strategic function } \\
\text { promote insights } \\
\text { from research and } \\
\text { feed back into } \\
\text { teaching and } \\
\text { postgraduate } \\
\text { students' research } \\
\text { projects. }\end{array}$ & $\begin{array}{l}\text { University } \\
\text { community } \\
\text { engagement policy } \\
\text { - focused on rules } \\
\text { of engagement with } \\
\text { participatory } \\
\text { frameworks that } \\
\text { facilitate } \\
\text { interaction. }\end{array}$ & $\begin{array}{l}\text { Feedback } \\
\text { mechanisms to } \\
\text { ensure these } \\
\text { activities are } \\
\text { linking research } \\
\text { to teaching and } \\
\text { how to engage } \\
\text { with the } \\
\text { community. } \\
\text { Workshops } \\
\text { between } \\
\text { researchers and } \\
\text { community - } \\
\text { learn - enrich } \\
\text { curricula } \\
\text { supported by } \\
\text { research } \\
\text { methodology of } \\
\text { participatory } \\
\text { frameworks } \\
\text { enriches depth } \\
\text { and quality of } \\
\text { research. }\end{array}$ \\
\hline $\begin{array}{l}\text { Forms and functions } \\
\text { of knowledge } \\
\text { production and } \\
\text { dissemination. }\end{array}$ & $\begin{array}{l}\text { Limited resources linked } \\
\text { to low level of research } \\
\text { output and a lack of } \\
\text { linkages with the external } \\
\text { environment. }\end{array}$ & $\begin{array}{l}\text { Better-focused } \\
\text { activities to ensure } \\
\text { sustainable } \\
\text { engagement } \\
\text { through research } \\
\text { which increased } \\
\text { research outputs } \\
\text { and attracting } \\
\text { external funding. }\end{array}$ & $\begin{array}{l}\text { University capacity } \\
\text { development } \\
\text { strategies, such as } \\
\text { academic-writing } \\
\text { and conference- } \\
\text { attendance policy } \\
\text { for dissemination of } \\
\text { research findings. }\end{array}$ & $\begin{array}{l}\text { Mechanisms: } \\
\text { Strategic plans } \\
\text { with targeted } \\
\text { outputs through a } \\
\text { range capacity } \\
\text { development } \\
\text { workshops. }\end{array}$ \\
\hline $\begin{array}{l}\text { Changes in form and } \\
\text { focus of engagement. }\end{array}$ & $\begin{array}{l}\text { The dynamic challenge } \\
\text { to pay back to } \\
\text { communities - to not be } \\
\text { extractive - plough } \\
\text { findings back into } \\
\text { communities but deal } \\
\text { with unrealistic hopes } \\
\text { and expectations of } \\
\text { communities in an } \\
\text { engaged way. }\end{array}$ & $\begin{array}{l}\text { The realisation of } \\
\text { contextual needs to } \\
\text { engage in a } \\
\text { developmental way } \\
\text { with key } \\
\text { stakeholders } \\
\text { through a dynamic } \\
\text { of increased } \\
\text { engagement } \\
\text { towards value and } \\
\text { quality which would } \\
\text { lead to the } \\
\text { establishing of a } \\
\text { culture of } \\
\text { scholarship } \\
\text { enhancement. }\end{array}$ & $\begin{array}{l}\text { Developed a } \\
\text { directorate of } \\
\text { engagement and } \\
\text { promote the } \\
\text { integration of the } \\
\text { core mission } \\
\text { through community } \\
\text { engagement } \\
\text { workshops and to } \\
\text { firmly establish } \\
\text { institutional } \\
\text { functions to support } \\
\text { faculties to fulfil the } \\
\text { mission of } \\
\text { community } \\
\text { engagement. } \\
\text { Create space for } \\
\text { intermediary } \\
\text { functions enhance } \\
\text { engagement } \\
\text { supported by } \\
\text { Database with all } \\
\text { community } \\
\text { projects. }\end{array}$ & $\begin{array}{l}\text { In response to } \\
\text { the sustainability } \\
\text { issues the need } \\
\text { to development } \\
\text { of intermediary } \\
\text { platform with the } \\
\text { agency through } \\
\text { which to create } \\
\text { such a platform } \\
\text { towards - } \\
\text { training, research } \\
\text { and engagement } \\
\text { which enhances } \\
\text { research as } \\
\text { integrated in } \\
\text { practice including } \\
\text { postgraduate } \\
\text { students to work } \\
\text { directly on real } \\
\text { issues. }\end{array}$ \\
\hline
\end{tabular}

The analytical framework used in this article should be considered contextually. Universities 
operate in very unique environments, which in turn are the product of specific influences, such as the socio-political and historical context of the region and country, and also the histories of modes of knowledge production and knowledge frameworks. Externally, influences like the adoption and application of policies and governance models have huge implications for transformation in universities.

Having said that it follows that the pathway approach followed in this article has implications for the way we look at the university's contribution to society beyond the mechanistic approach of traditional impact metrics. The relationships with communities from an engaged perspective recognises the contributions made towards the development of the scholarly foundations being developed by such an institution. The humanizing factor is a key component of this relationship and how knowledge production could be enriched.

We therefore proposed that future work also explores the usefulness of this framework to inform the development of a monitoring and evaluation framework for institutional change that goes beyond traditional mechanistic approaches.

\section{REFERENCES}

AAU. 2004. Accra Declaration on GATS and the Internationalization of higher education in Africa.

Arocena, Rodrigo and Judith Sutz. 2007. Universities, innovation and development processes in the changing global economy. 2007 Atlanta Conference on Science, Technology and Innovation Policy, October. Ieee, 1-11. doi:10.1109/ACSTIP.2007.4472899.

Brennan, John, Roger King and Yann Lebeau. 2004. The Role of Universities in the Transformation London: Association of Commonwealth Universities/The Open University.

Brundenius, Claes, Bengtåke Lundvall and Judith Sutz. 2009. The role of universities in innovation systems in developing countries: Developmental university systems - Empirical, analytical and normative perspectives. In Handbook of innovation systems and developing countries: Building domestic capabilities in a global setting, 311-33. Edward Elgar Publishing.

Castells, Manuel. 1994. The university system: Engine of development in the new world economy. Revitalizing Higher Education 1994: 14-40.

Castells, Manuel and Gustavo Cardoso. 2005. The network society: From knowledeg to policy, ed. Manuel Castells and Gustavo Cardoso. Washington, DC: John Hopkins Center for Transatlantic Relations.

Clark, Burton R. 2004. Delineating the character of the entrepreneurial university. Higher Education Policy. doi:10.1057/palgrave.hep.8300062.

Cloete, N., T. Bailey and P. Pillay. 2011. Universities and economic development in Africa. African Minds.

Coleman, James, S. 1986. The idea of the developmental university. Minerva 24(4): 476-94. doi:10.1007/BF01096709.

De Wet, Gideon. 2013. Introduction, in, beyond the apartheid university: Critical voices on transformation in the university sector. Edited by University of Fort Hare Press. Alice.

DoE, RSA. 1997. Education White Paper 3: A Programme for the Transformation of Higher Education. Pretoria: Department of Education. 
Etzkowitz, H. 2001. The second academic revolution and the rise of entrepreneurial science. IEEE Technology and Society Magazine 20: 18-29. doi:10.1109/44.948843.

Etzkowitz, Henry and Loet Leydesdorff. 2000. The dynamics of innovation: From national systems and 'mode 2' to a triple helix of university-industry-government relations. Research Policy. doi:10.1016/S0048-7333(99)00055-4.

Fort Hare. 2009. Strategic Plan 2009-2011: Towards Our Centenary. University of Fort Hare.

Fort Hare. 2014. University of Fort Hare Research Magazine. University of Fort Hare.

Gibb, Allan and Paul Hannon. 2006. Towards the entrepreneurial university? International Journal of Entrepreneurship Education 4: 73-110.

Gibbons, Michael. 1999. Science's new social contract with society. Nature 402: 81-84. doi:10.1038/35011576.

Govan Mbeki Research and Development Centre. 2009. University of Fort Hare Strategic Research Plan. University of Fort Hare.

Grobbelaar, S. and J. Kirkland. 2013. Institutionalising RU in Sub-Saharan African Universities. In International Association of Scientific and Technological University Libraries (IATUL). Cape Town, 16 April 2013. Cape Town.

Heyneman, S. P. 2003. The history and problems in the making of Education Policy at the World Bank 1960-2000. International Journal of Educational Development 23(3): 315-37. doi:10.1016/S0738-0593(02)00053-6.

Jones, Thomas, M. 2013. Instrumental stakeholder theory: A synthesis of ethics and economics. Academy of management review 20(2): 404-437.

Makhanya, M. 2014. The role of higher education in a developmental state. Professor Mandla Makhanya, Principal and Vice Chancellor, University of South Africa. Wednesday, 25 June 2014. Presentation at University of South Africa, Pretoria.

Meyns, Peter and C. Musamba. 2010. The developmental state in Africa: Problems and prospects. INEF-Report 101/2010.

NPC. 2011. National Development Plan. National Planning Commission, Sherino Printers, ISBN: 9780-621-41180-5.

Pillay, Pundy. 2011. Higher education and economic development: Literature review.

Schreuder, D. M. 2013. Universities for a new world: Making a global network in international higher education, 1913-2013. SAGE Publications.

Sehoole, C. and J. Knight. 2013. Internationalisation of African higher education: Towards achieving the MDGs. SensePublishers.

UNESCO. 1961. Conference of African States on the Development of Education in Africa. Addis Ababa, 15-25 May 1961.

Wilson, F. and V. Cornell. 2012. Strategies to overcome poverty and inequality: Towards Carnegie 3. SALDRU, University of Cape Town. 